TITLE:

\title{
ELECTRON MICROSCOPY ON THE PHOTORECEPTORS OF AN ANTHOMEDUSA AND A SCYPHOMEDUSA
}

$\operatorname{AUTHOR}(S)$ :

Yamasu, Terufumi; Yoshida, Masao

CITATION:

Yamasu, Terufumi ...[et al]. ELECTRON MICROSCOPY ON THE PHOTORECEPTORS OF AN ANTHOMEDUSA AND A SCYPHOMEDUSA. PUBLICATIONS OF THE SETO MARINE BIOLOGICAL LABORATORY 1973, 20: 757-778

\section{ISSUE DATE:}

1973-12-19

URL:

http://hdl.handle.net/2433/175744

RIGHT: 


\title{
ELECTRON MICROSCOPY ON THE PHOTORECEPTORS OF AN ANTHOMEDUSA AND A SCYPHOMEDUSA
}

\author{
Terufumi YAMASU and MASAo YOSHIDA \\ Tamano Marine Laboratory 2-3-3, Shibukawa, Tamano, Okayama, Japan 706
}

With 28 Text-figures

Some hydrozoan and scyphozoan medusae are known to have photoreceptors called eye spots or ocelli. In the hydromedusae the ocellus is situated at the aboral base of each tentacle, while the eye spots in the scyphomedusae are located on the marginal bodies called rhopalium near the bell margin. Studies on the structure of the ocelli of the hydromedusae have been limited to Polyorchis penicillatus. Though earlier investigators have reported a lens or Glaskörper by the light microscopy $(7,8)$. EAKIN and WestFall $(4,5)$ have disproved it and have further shown electron-microscopically that the photosensory cells belong to the primitive photoreceptor of the ciliary type (2). As regards the structure of scyphomedusan eyes, on the other hand, the classical observation on Aurelia aurita of SCHEWIAKOFF (1889), cited by BulLock (1) is probably the only one which has been done so far.

Work has been done in our laboratory on the physiological and photochemical aspects of the ocelli in the anthomedusa, Spirocodon saltatrix $(11,12,13$ and 14). However, since the basic morphological information which is important for interpreting experimental results is so scanty as above, we started to study the fine structure of cnidarian photoreceptors for the purpose of elucidating organization of sensory cells as well as their interrelationships with the second order neurons.

\section{Materials and Methods}

Two species, the anthomedusa, Spirocodon saltatrix (Tilesius) and the scyphomedusa and developing ephyrae of Aurelia aurita LAMARCK were used as materials.

Tentaclular bases of $S$. saltatrix and rhopalia of $A$. aurita were dissected out from freshly caught materials. They were fixed with $1.5 \%$ glutaraldehyde buffered by sodium cacodylate at $\mathrm{pH} 7.4$ for 1.5 hours at $0-4{ }^{\circ} \mathrm{C}$. The osmotic pressure was adjusted by adding sucrose to $8.5 \%$ at final concentration. Tissues surrounding the ocellus were cut off during the period of fixation. Materials were post-osmificated with $1 \% \mathrm{OsO}_{4}$ buffered by s-collidine at $\mathrm{pH} 7.4$ for $1.5-3$ hours at the same temperature. Materials in vials were shaken continuously on a shaker, Penetron Mark II (Sankay Inst.), throughout the period of fixation as well as that of raisin penetration in a mixture 
of raisin and propylene oxide. Materials were then embedded into Epon 812 raisin at $45^{\circ}$ and $60^{\circ} \mathrm{C}$ for 1 day each. Thin sections of silver color were cut by an LKB ultramicrotome and stained with uranyl acetate at first and then with lead citrate. Observations were carried out using Hitachi HU-11E and HS-8 electron microscopes.

\section{Results}

\section{Spirocodon saltatrix}

The ocellus of $S$. saltatrix is ectodermal and forms a papilla-like prominence by thickening of the ectoderm at the aboral base of each tentacle. The surface of the prominence is covered with microvilli projecting regularly except the entrance of the eye cup. The cup is about $70 \mu$ deep and the mouth part of it, about $30 \mu$ in diameter. The lumen of the concave cup is open to the outside without a lens structure. The cup is lined by a layer consisting of pigment and sensory cells which are both tall being sometimes over $50 \mu$ long, and desmosomes between neighboring cells are observed distinctly along the lateral boundaries at the distal ends. Micovilli and vesicles (Fig. 1. Mv and V) are found in the lumen. Though the microvilli protrude from both components, large vesicles seem to be originated only from the sensory cells. As noted in Polyorchis, the vesicles and microvilli arrange in random direction.

The sensory cells (Fig. 1. SC) can be easily distinguished from the pigment cells under the electron microscope for they include ciliary apparatus (Fig. 2. C), mitochondria and vesicles, while the latter (Fig. 1. PC) are filled with pigment granules of 0.2-0.6 $\mu$ in diameter in this region. The distribution of sensory cells is not restricted to a certain site but they are scattered among a larger number of pigment cells. In the central part of the cup, however, there is a tendency that the two types of cell are arranged alternately (Fig. 1. SC and PC), but sometimes two sensory cells can be seen side by side.

Each sensory cell bears a long cilium with 9 doublets and 2 singlets (Fig. 2. C). The cilium has a quite long rootlet. Its shaft becomes sometimes wider in the upper part and branches off few microvilli which extend into the cup lumen (Fig. 2. Mv). The pigment cells are provided with microvilli which extend into the cup lumen from the distal ends (Fig. 3. Mv). They are more electron dense than those of sensory cells, and contain small pigment granules (Fig. 3. PG) and branch out into finer ones in the in the lumen (Fig. 3. Br).

The middle portion of the sensory cells is slender showing a cylindrical shape in general and becomes thick near the basal region (Fig. 4), where organelles which are commonly found in other photoreceptive cells, such as mitochondria, Golgi bodies and numerous small vesicles, are included together with few large vacuoles (Fig. 4. Mt, G, V and Va). A number of small vesicles are scattered specifically near and adjacent to the Golgi bodies, suggesting that they may have just been released from the bodies (Fig. 4 and 4, V). Other types of cytoplasmic organelle are more clearly 
shown in Figs. 6 and 7, in which many microtubules are seen running in parallel with the cell axis (Fig. 6. Mi and magnified in Fig. 7).

The pigment cells in this region contain pigment granules which are larger than those in the distal region (Figs. 4 and 6. PG). The largest one may become $5 \mu$ in diameter. The granules in this region show a wide variation in appearance. Thus some are almost empty (Fig. 6. PG, right lower one), but others are either more dense (Fig. 6. PG, right upper one) or vacuolated (Fig. 4. PG), suggesting that the pigment substance has been extracted to varying degrees during the course of dehydration procedure. The variation in appearance as observed on the smaller pigment granules in the distal portion of the pigment cell in Fig. 1 is probably due to the same cause. The nucleus of the pigment cell (Fig. 4. N) is located near the basal end with a nucleolus. Cytoplasm around the nucleus is slightly more electron dense and contains a few mitochondria, Golgi bodies and small vesicles. The distal and the middle regions of the pigment cells, on the contrary, are loaded with a number of the pigment granules, whereas mitochondria and small vesicles are found only few. Details of the basal region of the sensory cell are shown in Figs. 8 and 9. Here several electron dense bodies (DB) either multilayered or vacuolated are found in the vicinity of the nucleus. They also appear near the Golgi bodies together with numerous small vesicles. The nucleus of the sensory cell lies below the basal thickening (Fig. 9. N) with a large nucleolus (Fig. 9. No) near the center.

Bipolar cells have been observed on a peripheral portion of the eye cup under the light microscope, but not under the electron microscope as yet. Desmosomelike structure occurs frequently in the region where the basal parts of the sensory cells appear to be in contact with the nerve net. These might be synaptic sites but it is rather puzzling that what appear to be cored synaptic vesicles have been found on the side of the nervous tissue and never on the side of the sensory cells.

\section{Aurelia aurita}

a. The large ocellus.

The large ocellus is situated on the aboral side of the rhopalium. It consists of a single layer of cells bearing pigment granules of varying sizes, about $0.5 \mu$ in the distal region and over $3 \mu$ in the basal (Fig. 10, PG). The pigment cell is provided with a cilium of 9-2 type (C) which is surrounded by a tuft of microvilli (Mv). Larger granules are often found containing crystaline substances $(\mathrm{Cr})$. Other organelles such as mitochondria (Mt) and nucleus (N) are localized in the basal region of the cell. Whether or not these pigmented cells are in fact photosensory is not certain, but it must be mentioned that synapse-like structures with cored vesicles on both sides of the thickened membrane have been observed frequently in the region where the pigment cells are in contact with the nerve net.

b. The small ocellus.

The small ocellus is situated on the oral side of the rhopalium. It differs entirely 
in the structure from either the large one or that of Spirocodon. It consists of an epithelium, a mass of sensory cells (Fig. 11. MSC) and a nerve net work in the ectoderm and a single layer of pigment cells in the endoderm (PCL). The ecotdermal and endodermal components face each other across a thin layer of mesoglea $(\mathrm{Mg})$ which forms a bottle-shaped cup by invagination. The cup is about $40 \mu$ in depth.

A part of the mass of sensory cells is shown in Figs. 12 and 13. Sensory cell bodies are thin and tall. Each cell contains a large and elongated nucleus $(\mathrm{N})$. The cytoplasm is rich in organelles such as mitochondria (Mt), endoplasmic reticulum (ER), glycogen granules (Gl) and multilayered bodies (MB).

That the sensory cells of the small ocellus belong to the 9-2 type ciliary cell is clearly demonstrated in figures from 12 to 16 . A cluster of cross and oblique sections of cilia appear in the close vicinity of the thin mesoglea (Figs. 11 and 12. C), and fragments of rootlets $(R)$ can be seen in a number of cells in one section. When cut longitudinally, the characteristic pattern of striation can be clearly observed (Fig. 14. R). The origin of the microvilli is not clear at present. As shown in Figs. 13 and 15 (C), however, parts of microvilli are seen in the widened space of the ciliary shaft. This suggests that at least some of the microvilli are originated from the ciliary shaft. It can not be determined whether or not some others may protrude directly from the cell surface.

Another important feature as regards the ciliary arrangements is that they appear mostly in pair. This is clearly seen in Fig. 16, where two ciliary bases (CB) exist in one cell with two rootlets $(\mathrm{R})$ running in two directions. Distal parts of the cilia also appear frequently in pair as shown in Fig. $17\left(\mathrm{C}_{1}, \mathrm{C}_{2}\right.$ and $\left.\mathrm{C}_{3}\right)$.

The pigment layer is endodermal, differing from either that of the large ocellus of the same species or of $S$. saltatrix. It attaches tightly to the mesoglea in a row. Pigment granules are from 0.2 to $0.6 \mu$ in diameter. Two types of the pigment cells are distinguishable (Figs. 11 and 18. $\mathrm{PC}_{1}$ and $\mathrm{PC}_{2}$ ), one with electron dense pigment granules $\left(\mathrm{PC}_{1}\right)$ and the other with less dense granules $\left(\mathrm{PC}_{2}\right)$. Though we have made no chemical tests, pigments contained in $\mathrm{PC}_{2}$ may be considered to be more fat soluble. Nuclei are found in the basal region of the cells (Fig. 19. N). Rough surfaced endoplasmic reticulum sometimes surrounds mitochondria and the nucleus (Fig. 19. ER).

The small ocellus is thus revealed to possess a rather unusual feature as a primitive photoreceptor in that the free surfaces of the sensory cells lie at the innermost region of the ectoderm. This implies that the sensory cells must have invaginated at some

Fig. 1. An electron micrograph showing the distal part of the sensory-pigment layer of Spirocodon saltatrix.

Fig. 2. The distal part of the sensory cell provided with a 9-2 type cilium, the shaft of which is widened in the middle part and branches into few microvilli in the upper end.

Fig. 3. The distal part of the pigment cell showing extensions of the microvilli which contain pigment granules and finer branches. Unless otherwise indicated, the solid bar shows 1 micron. $\mathrm{Br}$, branch of the microvilli from the pigment cell; $\mathrm{C}$, cilium; $\mathrm{Mv}$, microvilli; $\mathrm{PC}$, pigment cell; PG, pigment granule; SC, sensory cell; $\mathrm{V}$, vesicle. 


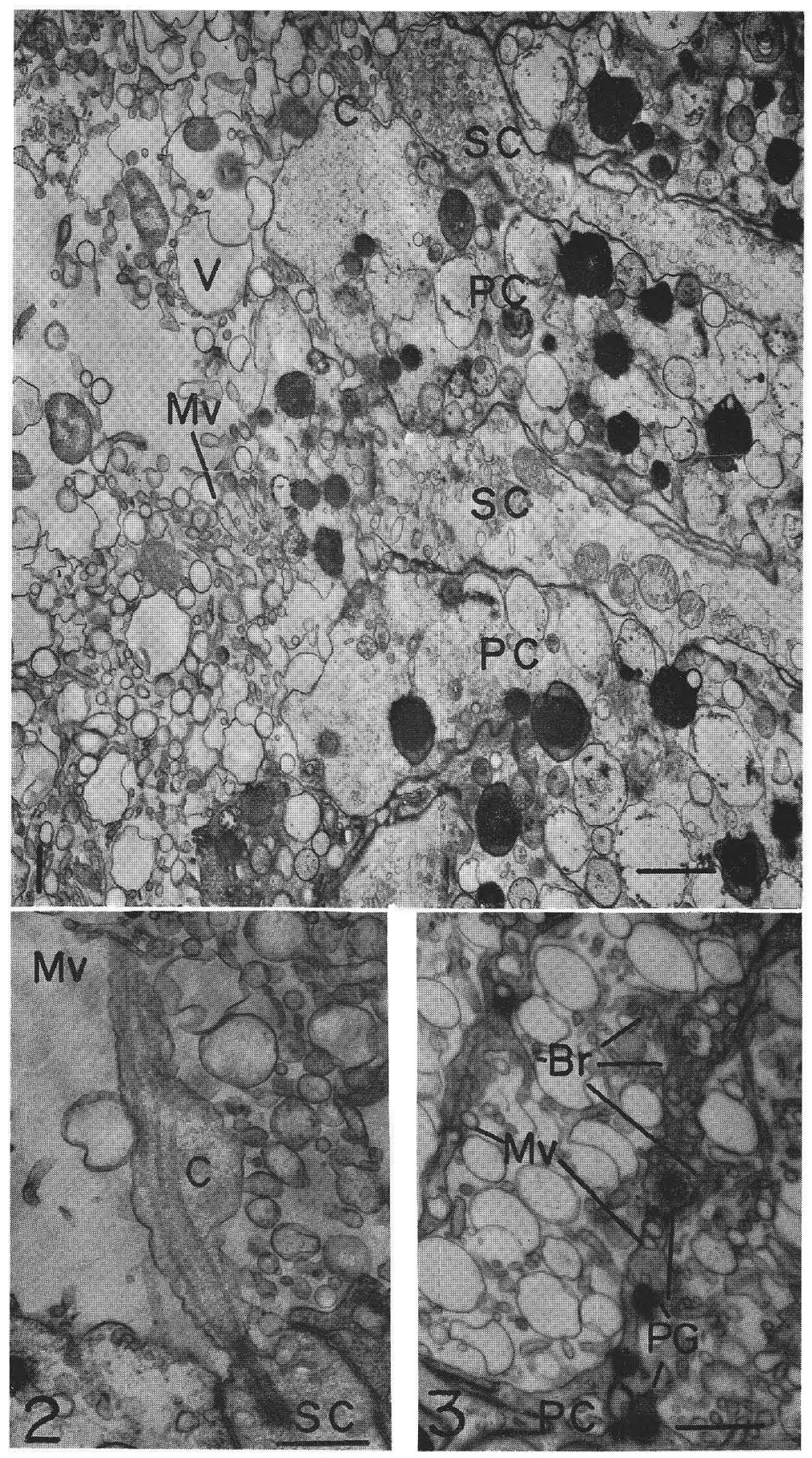



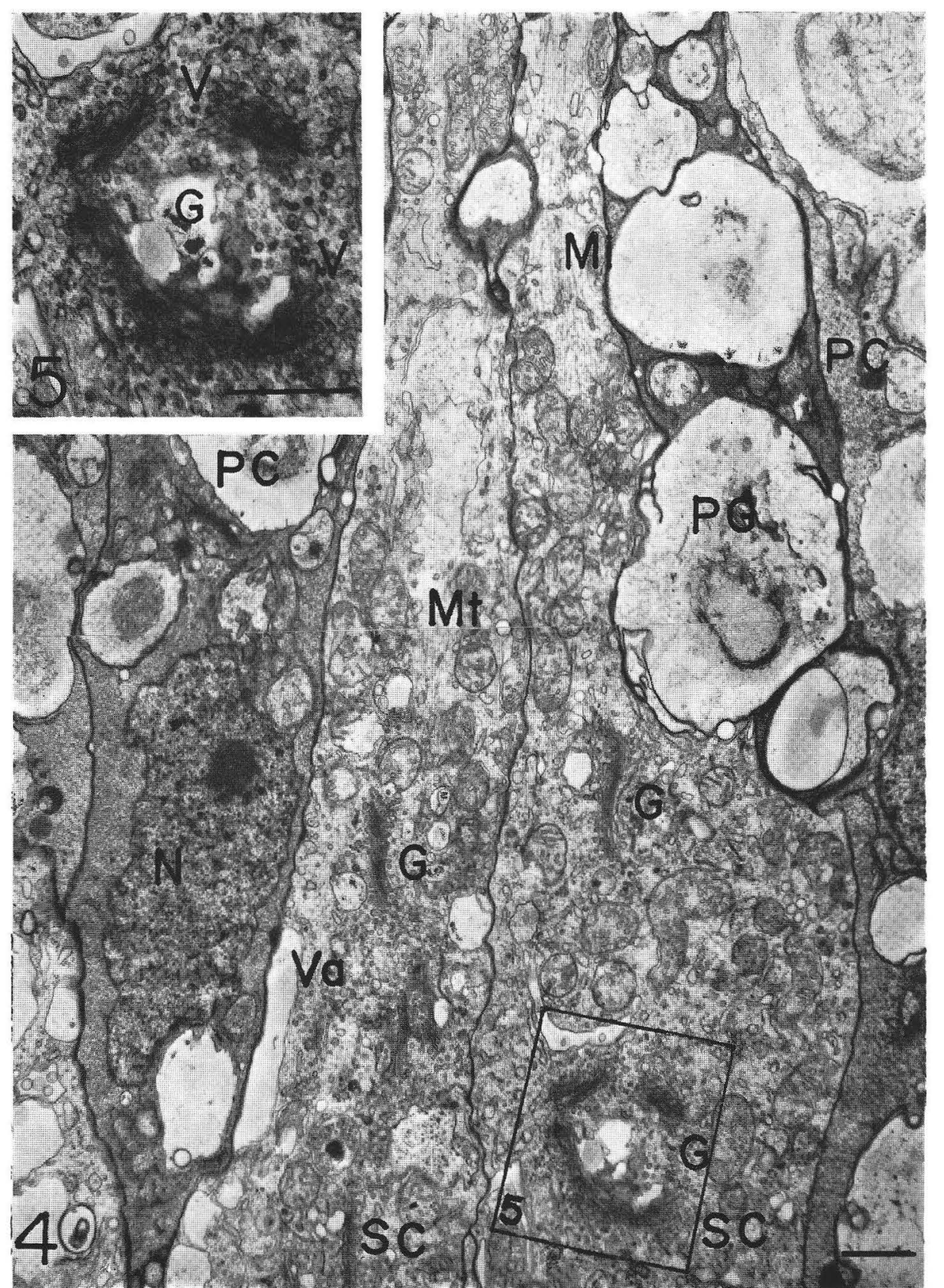

Fig. 4. The middle part of the sensory cell, showing cytoplasmic components. Two sensory cells lie side by side and the basal parts of two pigment cells are observed on either side of the two sensory cells.

Fig. 5. A highly magnified figure of the Golgi body showing the relationship between the body and the small vesicles.

$\mathrm{G}$, Golgi body; Mi, microtubule; Mt, mitochondrion; N, nucleus of the pigment cell; PC, pigment cell; PG, pigment granule; SC, sensory cell; V, vesicles; Va, vacuole. 


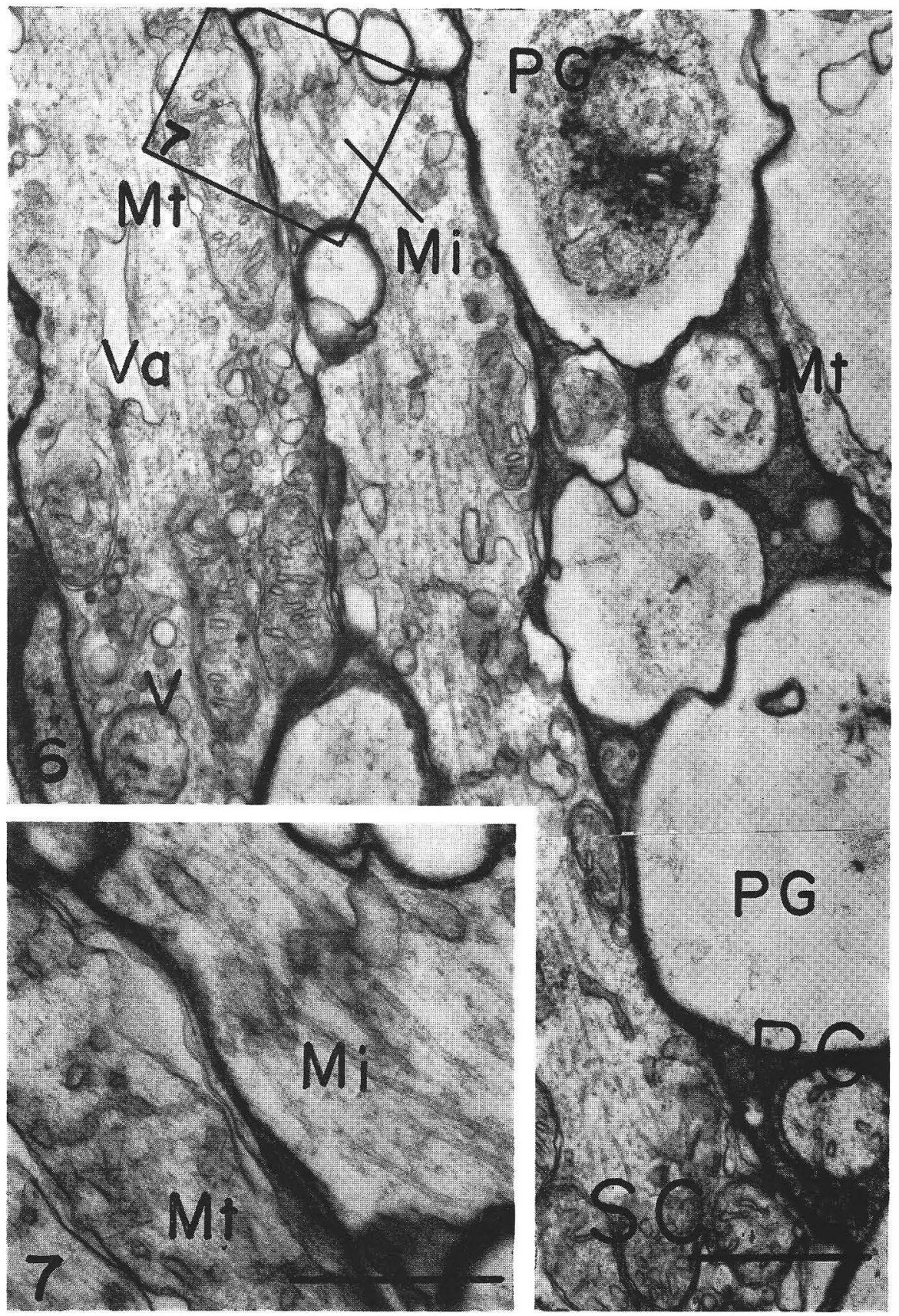

Fig. 6. The middle part of the sensory cells showing cytoplasmic organelles.

Fig. 7. An enlargement of a part of Fig. 6 showing details of the microtubules.

Mi, microtubule; Mt, mitochondrion; PC, pigment cell; PG, pigment granule; SC, sensory cell; V, vesicle; Va, vacuole. 


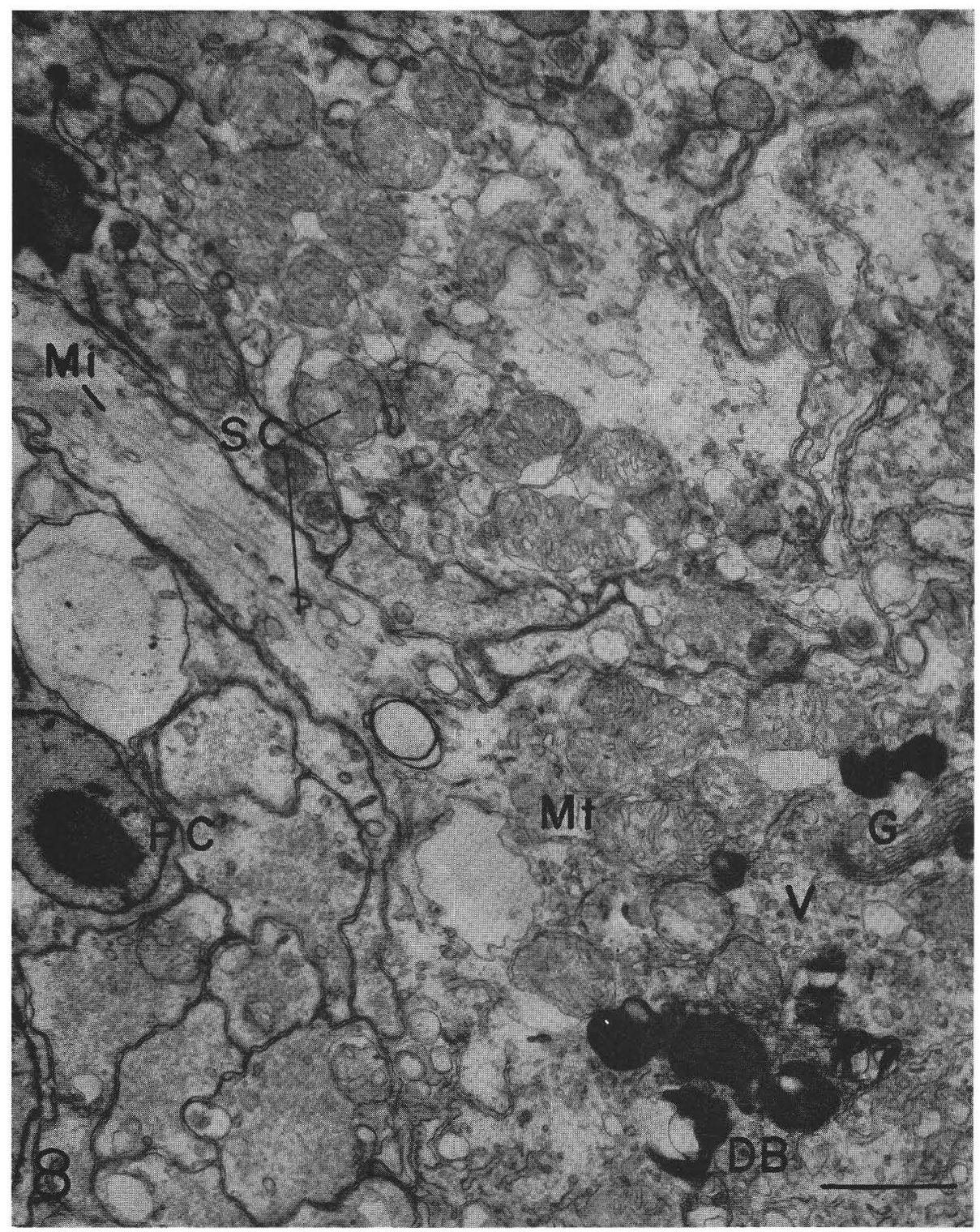

Fig. 8. An electron micrograph showing the basal region of a sensory cell. Several electron dense bodies can be seen in the lower right part of the figure.

DB, electron dense body; G, Golgi body; Mi, microtubule; Mt, mitochondrion; PC, pigment cell; SC, sensory cell; V, vesicles. 


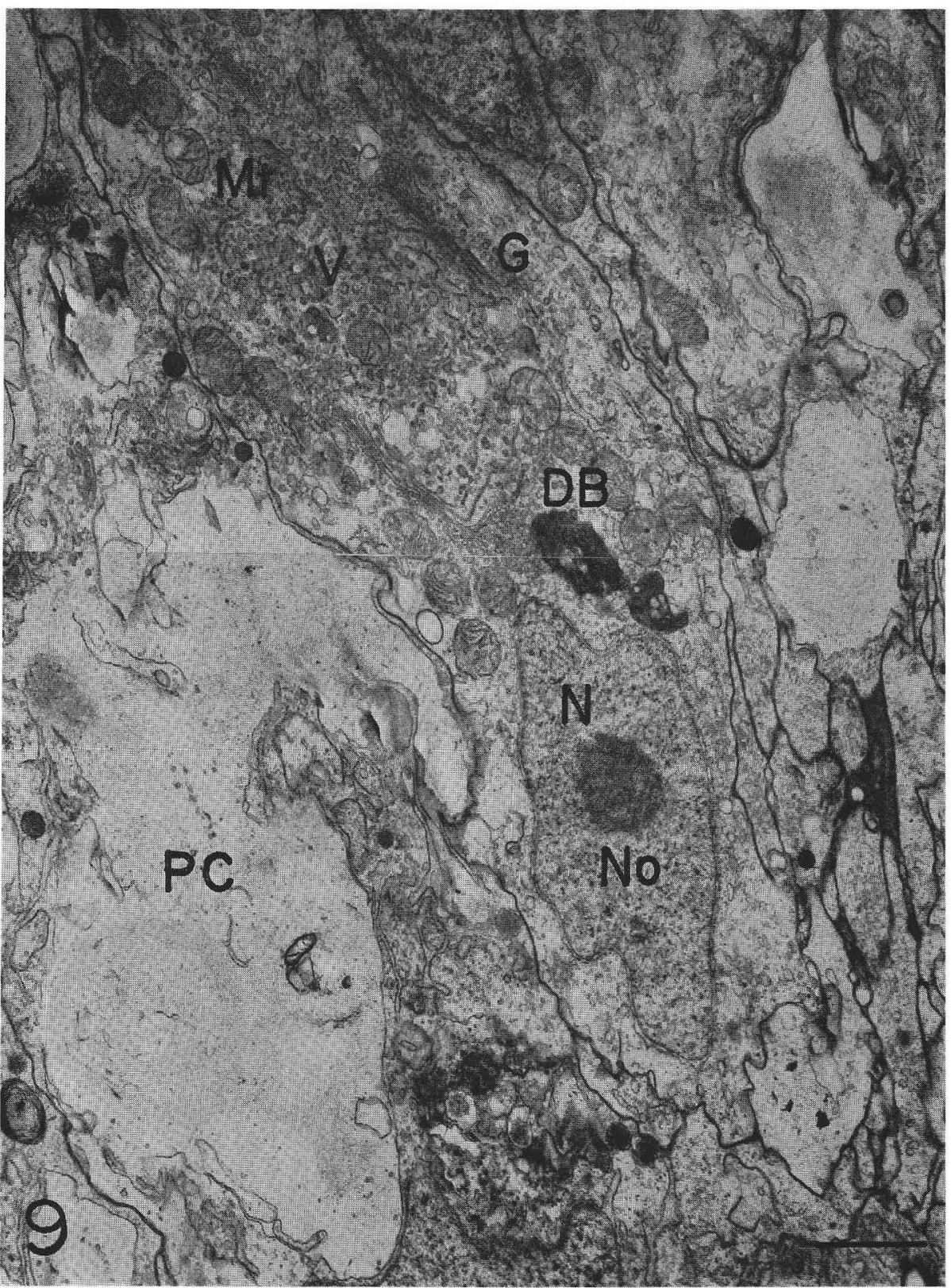

Fig. 9. An electron micrograph of the basal part of the sensory cell showing a nucleus in the basal end.

$\mathrm{DB}$, electron dense body; G, Golgi body; Mt, mitochondrion; N, nucleus; No, nucleolus; PC, pigment cell; V, vesivles. 


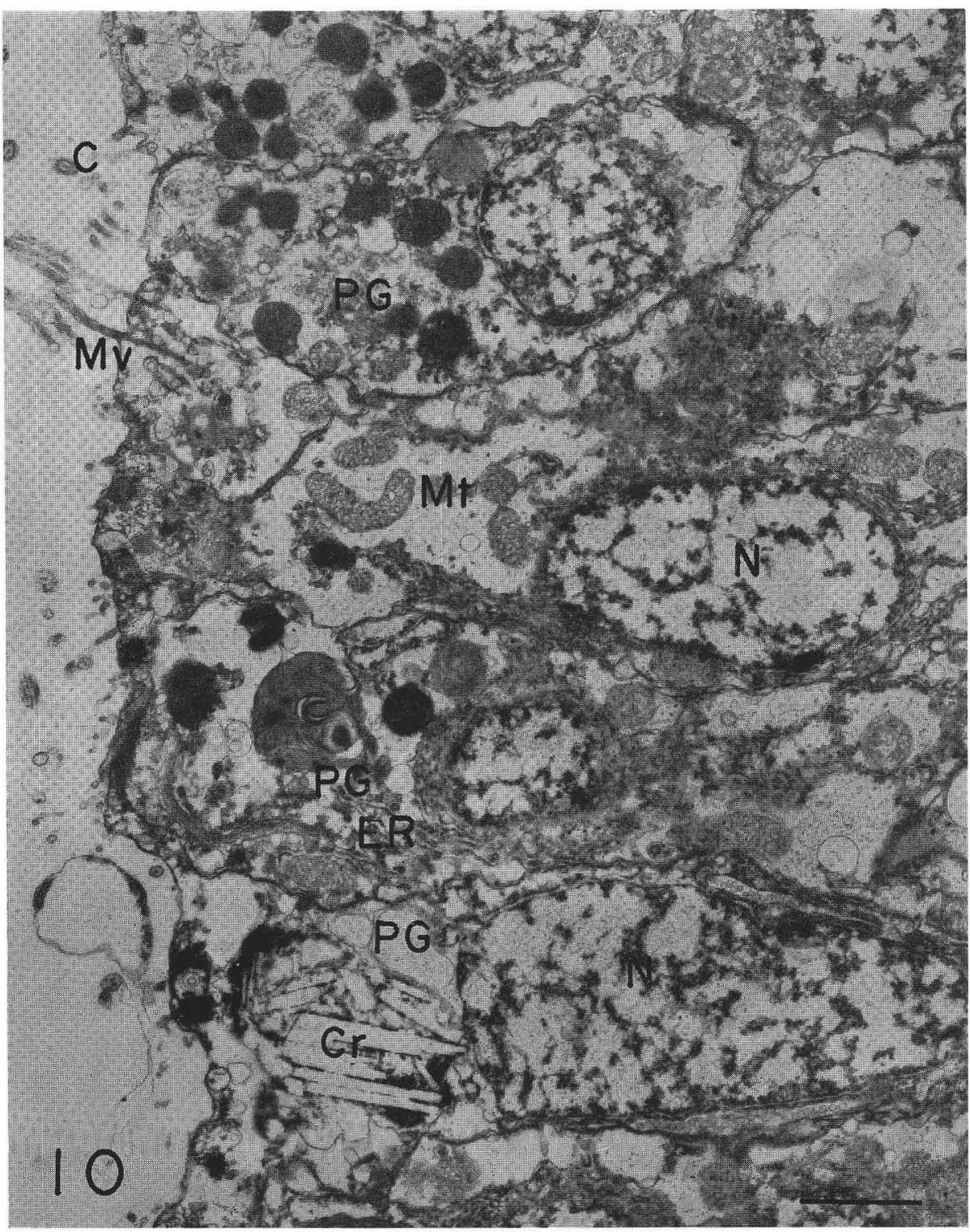

Fig. 10. An electron micrograph of the large ocellus of a young ephyra, showing its organelles.

$\mathrm{C}$, cilium; $\mathrm{Cr}$, crystaline substance; ER, endoplasmic reticulum; Mt, mitochondrion; Mv, microvilli; N, nucleus; PG, pigment granule. 


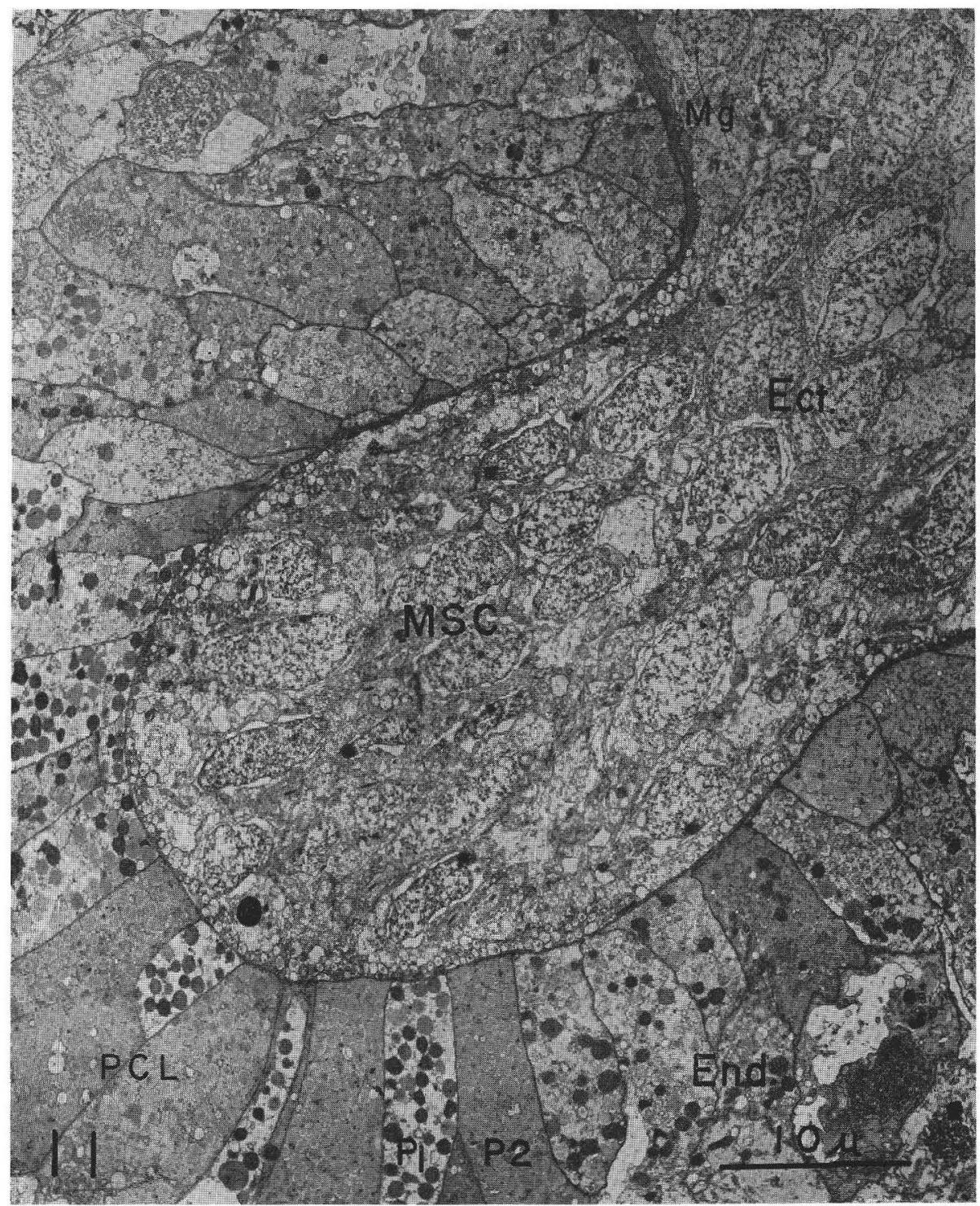

Fig. 11. An electron micrograph of the small ocellus of Aurelia aurita, showing the bottleshaped invagination of the mesoglea. A mass of sensory cells is seen within the cup and a layer of pigment cells, in the endoderm across the mesoglea. Epithelial and nerve layers, both out of the figure, cover the sensory cell mass. The solid bar shows 10 microns.

Ect, ectoderm; End, endoderm; $\mathrm{Mg}$, mesoglea; $\mathbf{P}_{1}$, pigment cell containing electron dense granules; $\mathrm{P}_{2}$, pigment cell containing less dense granules; $\mathrm{PCL}$, pigment cell layer; $\mathrm{MSC}$, a mass of sensory cells. 

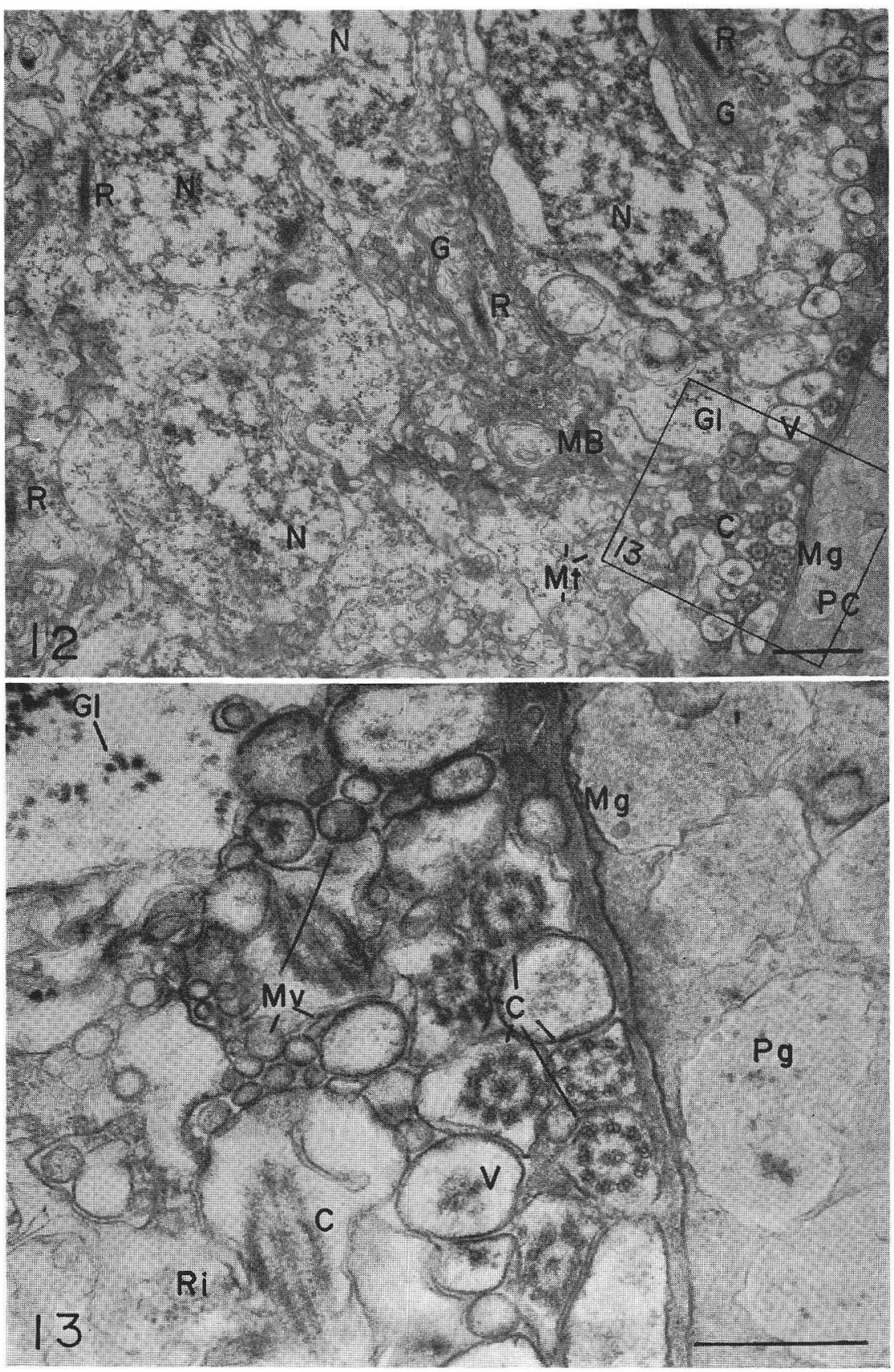

Fig. 12. An electron micrograph of the sensory cells near the mesoglea, showing organelles, cytoplasmic inclusions and cilia which extend from the surfaces of the sensory cells.

Fig. 13. An enlargement of a part of Fig. 12, showing 9-2 type cilia, vesicles and microvilli. C, cilia; G, Golgi body; Gl, glycogen granules; MB, multilayered body; Mg, mesoglea; $\mathrm{Mt}$, mitochondrion; $\mathrm{R}$, ciliary rootlet; Ri ribosome; $\mathrm{V}$, vesicle. 

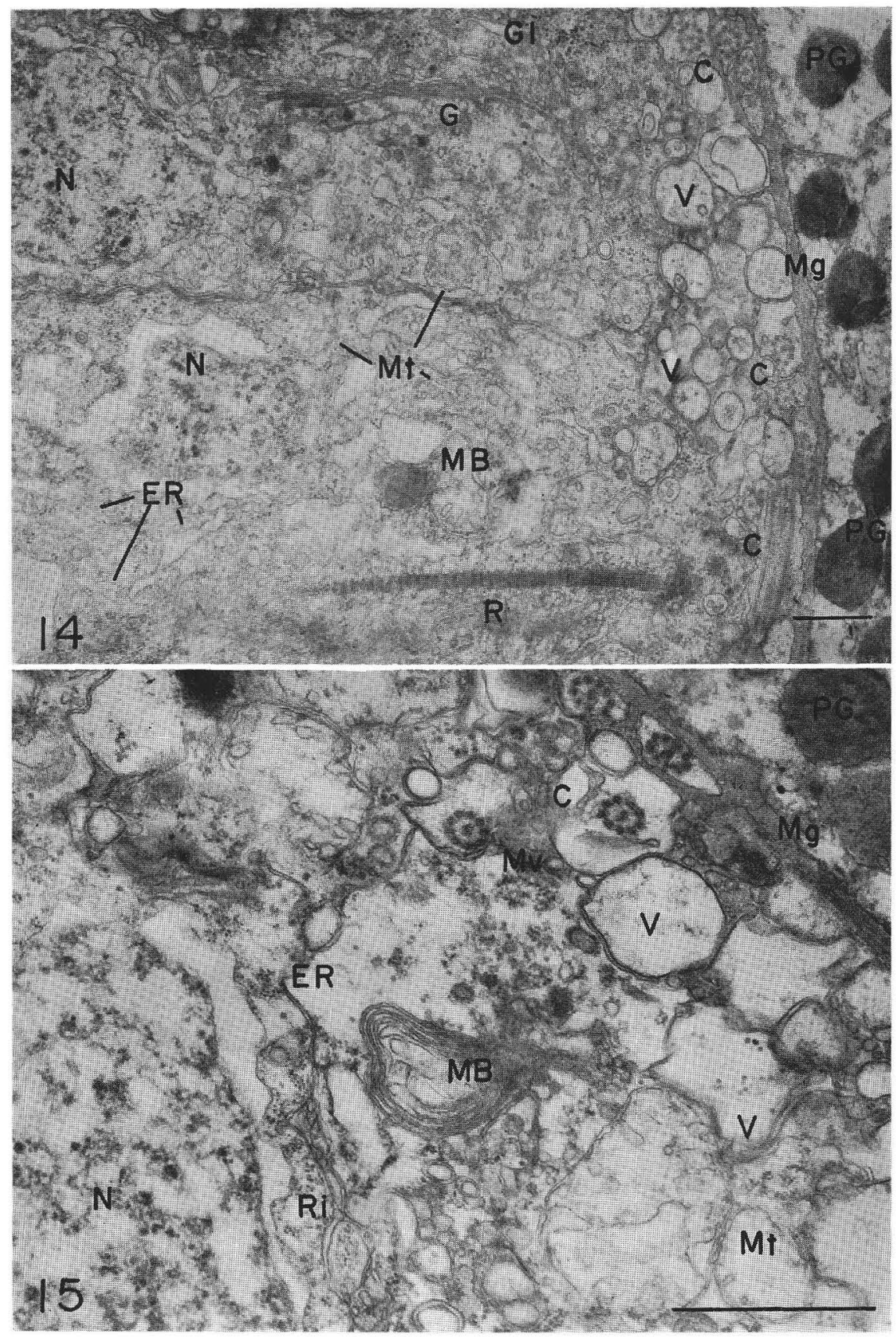

Fig. 14. An electron micrograph of the sensory cell, showing a long ciliary rootlet in the lower part of the figure.

Fig. 15. An electron micrograph showing the multilayered body in the sensory cell. C, cilium; ER, endoplasmic reticulum; G, Golgi body; G1, glycogen granules; $M B$, multilayered body; $\mathrm{Mg}$, mesoglea; Mt, mitochondrion; $\mathrm{Mv}$, microvilli; $\mathrm{N}$, nucleus of the sensory cell; $\mathrm{PG}$, pigment granule; $\mathrm{R}$, ciliary rootlet; $\mathrm{Ri}$, ribosomes; $\mathrm{V}$, vesicle. 

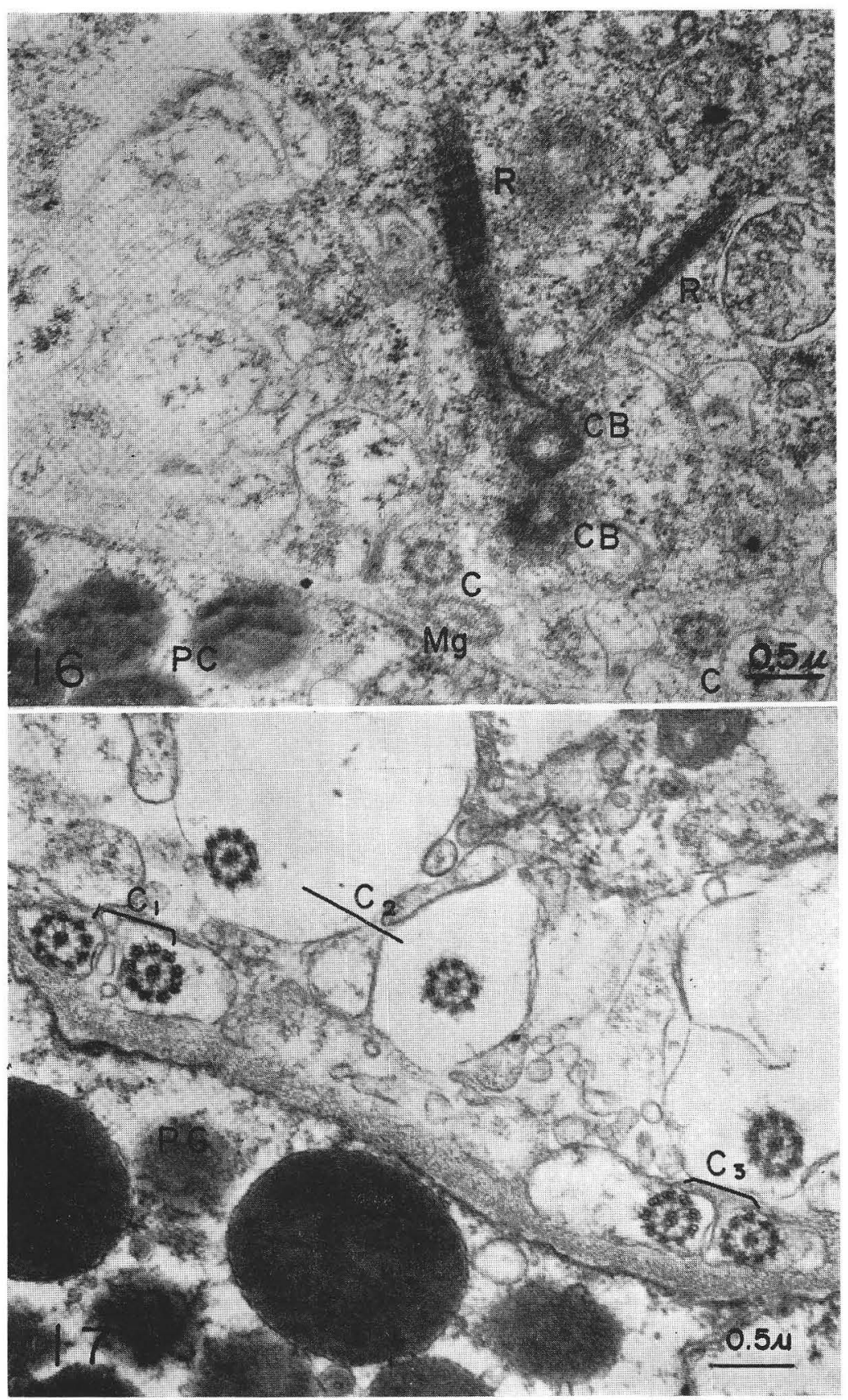

Fig. 16. An electron mi micrograph, showing a pair of ciliary bases. One of the ciliary base is accompanied by a pair of rootlets.

Fig. 17. An electron micrograph, showing three pairs of cilia, $C_{1}, C_{2}$ and $C_{3}$. $\mathrm{C}$, cilia; $\mathrm{CB}$, ciliary base; $\mathrm{Mg}$, mesoglea; PC, pigment cell; PG, pigment granule; R, ciliary rootlet. 

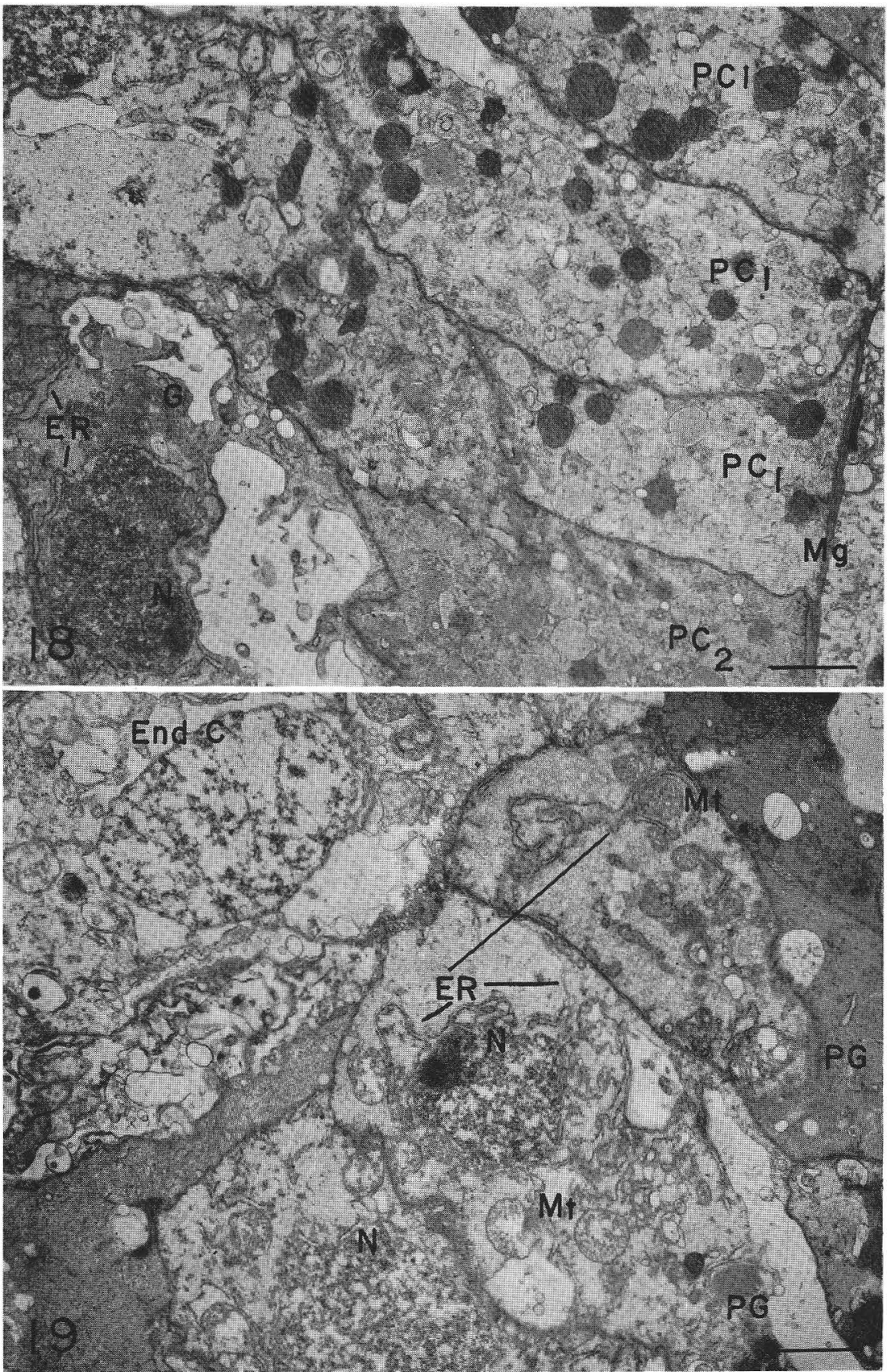

Fig. 18. An electron micrograph of the upper part of the pigment cell.

Fig. 19. The nuclear part of the pigment cell.

ER, endoplasmic reticulum; End C, endodermal cell; G, Golgi body; Mg, mesoglea; $\mathrm{Mt}$, mitochondrion; $\mathrm{N}$, nucleus of the pigment cell; $\mathrm{PC}$, pigment cell; $\mathrm{PC}_{1}$, pigment cell containing electron dense granules; $\mathrm{PC}_{2}$, pigment cell containing less dense granules; $\mathrm{PG}$, pigment granule. 


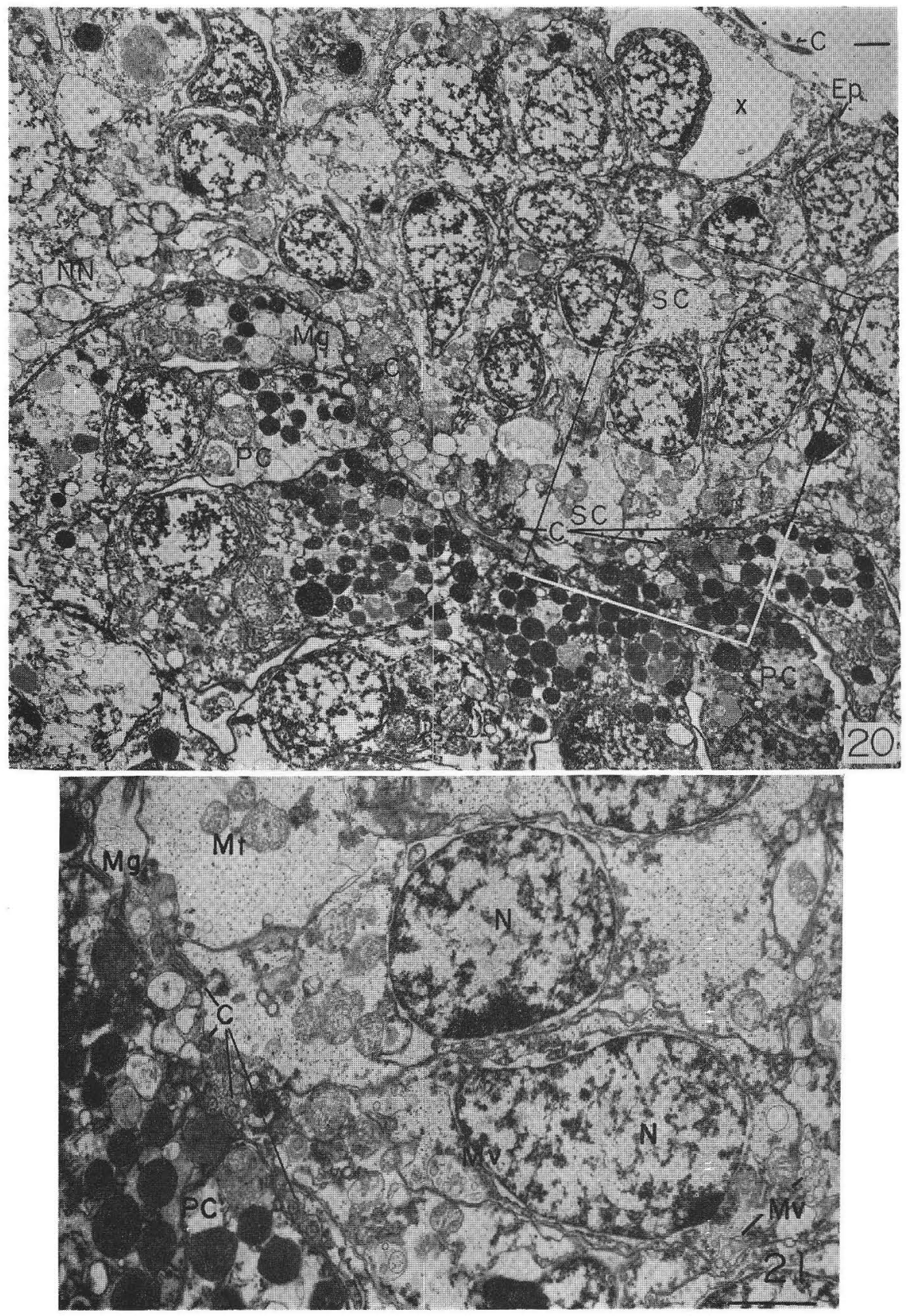

Fig. 20. An electron microgrph of the small ocellus of an ephyra 10 days after the release from the strobila. The central part forms a shalow cup by invagination of the mesoglea.

Fig. 21. A magnified electron micrograph of a part of Fig. 20, showing details of the bottom part of the eye cup.

C, cilia; Ep, epithelial cell; Mg, mesoglea; Mt, mitochondrion; Mv, microvilli; $\mathrm{N}$, nucleus of the sensory cell; NN, nerve net; No nucleolus; PC, pigment cell; SC, sensory cell; $\mathrm{V}$, vesicles; $\mathrm{X}$, an open space between the sensory cell and the epithelial cells near the surface of the small ocellus. 


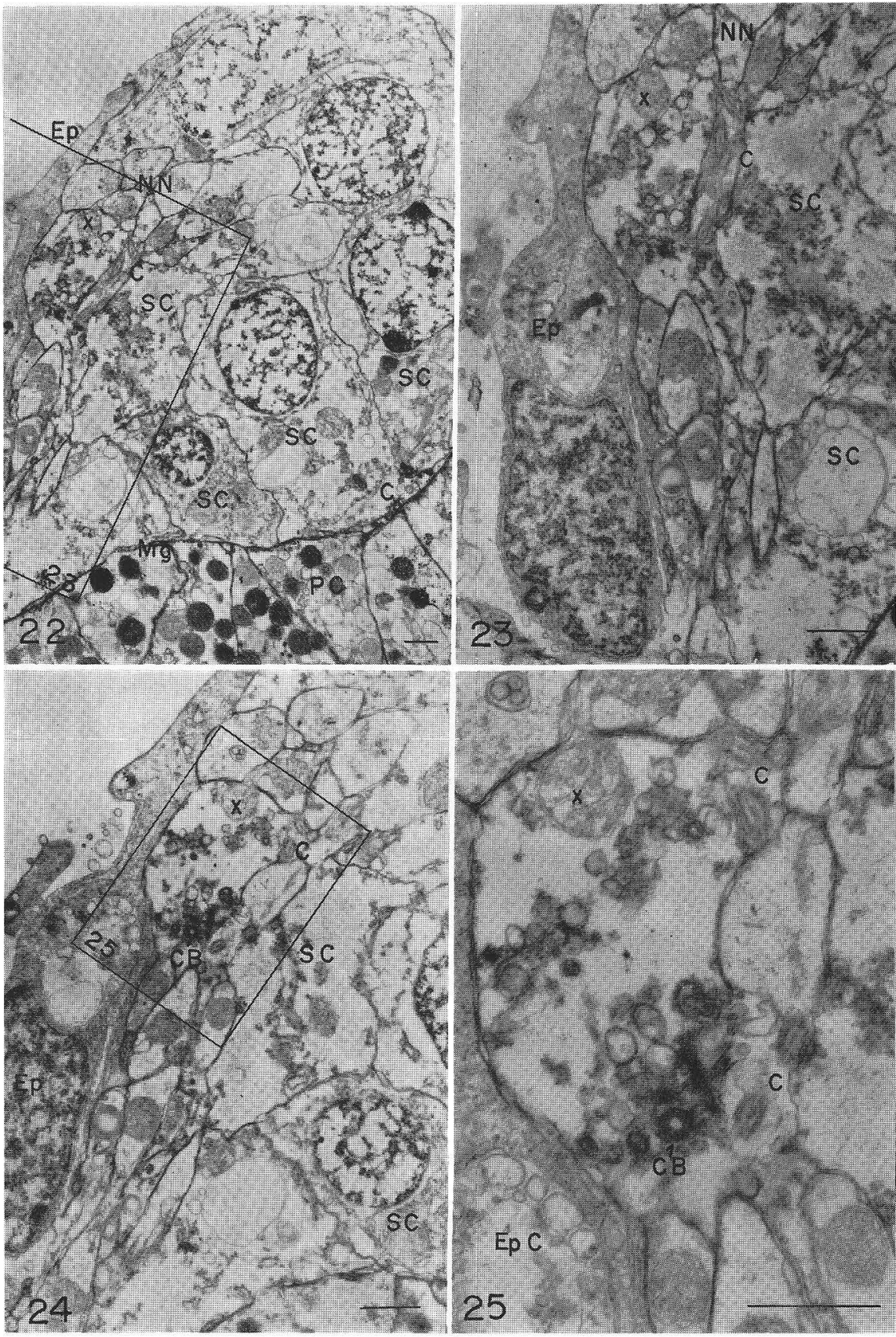

Fig. 22. An electron micrograph of the small ocellus of a young ephyra, showing a cell which is probably in the process of invagination carrying a pair of cilia with it.

Fig. 23. A magnified micrograph of Fig. 22.

Fig. 24. An electron micrograph of a section separated by a few sections from that of Fig. 22 , showing a basal part of the cilia of the same cell.

Fig. 25. A magnified micrograph of Fig. 24.

$\mathrm{C}$, cilia; $\mathrm{CB}$, ciliary base; Ep, fiat epithelial cell; $\mathrm{Mg}$, nesoglea; $\mathrm{NN}$, nerve branch; $\mathrm{PC}$, pigment cell; $\mathrm{SC}$, sensory cell; $\mathrm{X}$, see the text. 

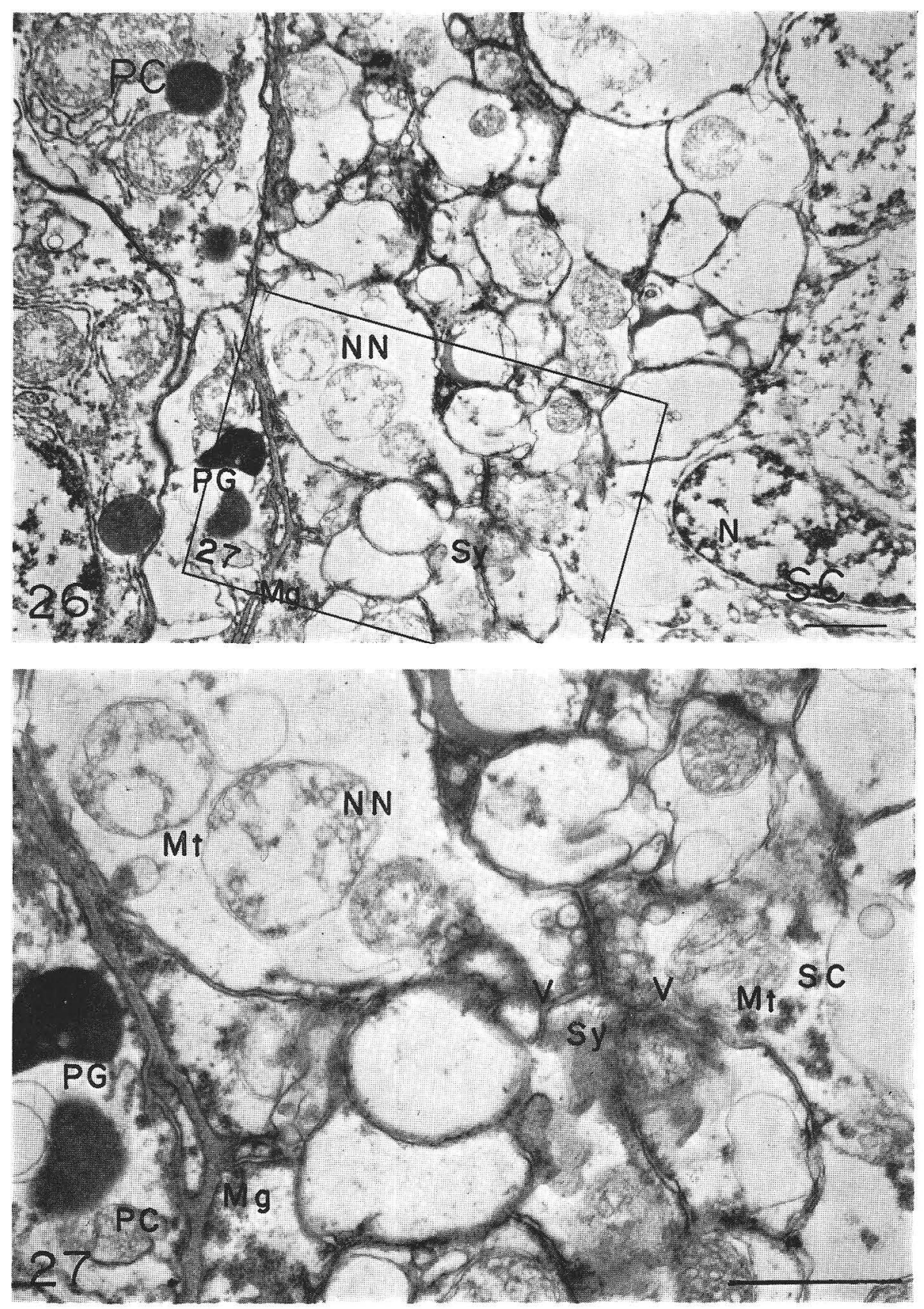

Fig. 26. An electron micrograph of the small ocellus of an early stage ephyra, showing the synapse between the sensory cell and the neuron.

Fig. 27. A magnified figure of Fig. 26. Cored vesicles are found on both sides of the synapse. $\mathrm{Mg}$, mesoglea; Mt, mitochondrion; $\mathrm{N}$, nucleus of the sensory cell; NN, neuron; PC, pigment cell; PG, pigment granules; SC, sensory cell; Sy, synapse: V, synaptic vesicles. 


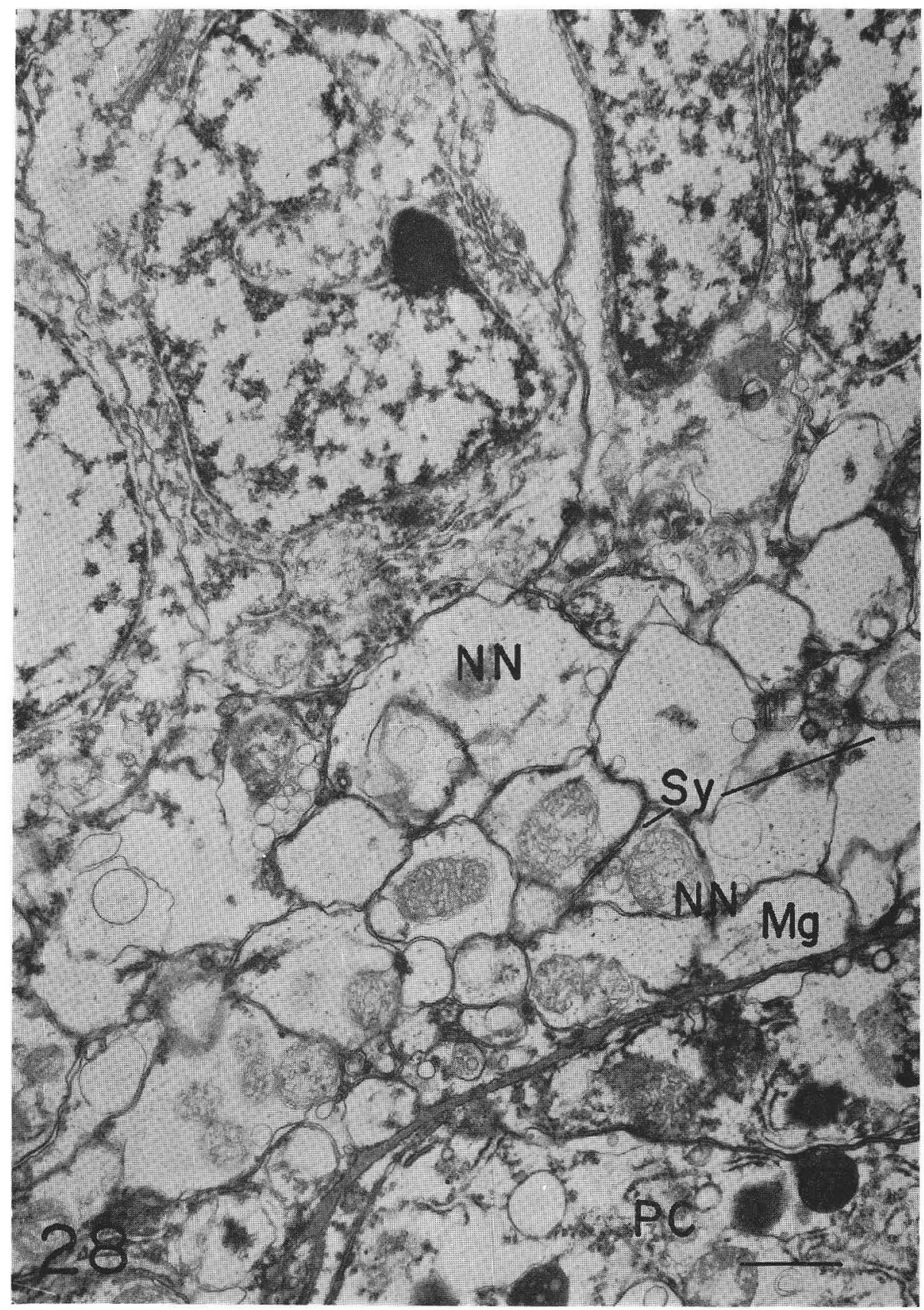

Fig. 28. An electron micrograph showing synapses between neurons. The synaptic vesicles are found on both sides.

$\mathrm{Mg}$, mesoglea; NN, neurons; PC, pigment cell; Sy, synapses. 
stage of differentiation. When and how such a process of invagination occurred was studied by tracing back to developing ephyrae. Figure 20 shows the central part of the developing small ocellus of an ephyra 10 days after the release from a strobila. The mesoglea $(\mathrm{Mg})$ forms already a concave shape, though still shallow. Some of the sensory cells (SC) with a pair of cilia (C) face the mesoglea, as shown more clearly in Fig. 21 by a higher magnification. The outer surface of the ocellus is covered with flat epithelial cells (Ep), beneath which is seen a cell separated by an open space (marked by $\mathrm{X}$ ). Such open Spaces have been observed in all the specimens examined, though the sizes vary to some extent.

We have traced further back to the earlier stage of development of the ephyra and finally found what appears to be an intermediate of the process of invagination (Figs. 22, 23, 24 and 25). In Fig. 22, three sensory cells at the center (SC) facing the mesoglea $(\mathrm{Mg})$ appear to have already differentiated. There is a narrow space where a pair of cilia (C) are seen between the part marked by an X and a sensory cell (SC). A more precise figure is presented in Fig. 23. Adjacent to the mark $\mathrm{X}$ can be noted nerve branches (NN). Epithelial cells are very flat (Ep). Figure 24 was taken from a section separated by a few sections from the previous one (Fig. 22). There is a ciliary base (CB) at the site which corresponds to that in Fig. 22 where the pair of cilia are seen. The highly magnified figure (Fig. 25) shows clearly that the cytoplasm is continuous to the doublet (C). These observations indicate that the pair of cilia as seen in Fig. 22 have their origin in the cell marked by the X. It is thus highly likely that the sensory cells are derived from the surface region as shown in Fig. 20. They invaginate with their free surfaces pointing toward the mesoglea which also invanginates during successive developmental processes.

Young ephyrae are advantageous in studying the fine structure of sensory-nerve junctions, for the ocellus of the ephyra consists of a smaller number of sensory cells and simpler nerve net work compared with that of the adult medusae. Figures 26 and 27 show a junction (Sy) between a sensory cell (SC) and a neuron (NN). Cored synaptic vesicles (V) appear on both sides of the junction. Synapses between neurons also bear vesicles on both sides as seen in Fig. 28 (Sy).

\section{Discussion}

Electron microscopic studies on primitive photoreceptors have recently advanced considerably (for review, see EAKIN, 1972). Apart from the work of EAKIN and WESTFALL (4) on Polyorchis, however, there has been no report on the fine structure of coelenterate photoreceptor, though they show a wide and interesting spectrum in the degree of differentiation, i.e., from simple ocelli to well-developed lens eyes (for review, see Bullock, 1965). The present work on S. saltatrix has confirmed the notion on hydromedusan ocelli (4) in its essence, e.g., the lack of a lens, the ciliary nature of sensory cells with microvilli as outgrowth of the ciliary shaft, the organization of 
pigment cells and their microvilli, etc.

The large ocellus of $A$. aurita consists of a single layer of pigmented cells, each bearing a cilium surrounded by a tuft of microvilli. If it is in fact a photoreceptive organ, its organization is much simpler than that of the hydromedusae. Considering that the synapse-like structures appear between these cells and the underlying nerve net work and also that potential photoreceptive function has been suggested for pigmented ciliary cells in bryozoan larvae (10), the large ocellus may eventually be proved as a photoreceptor.

The small ocellus shows a structure much more complicated than that of the hydromedusae. The inverted retina is not uncommon in higher animals. This happens so even in much simpler forms such as planarian ocelli. It is interesting to note that coelenterates which are one of the simplest animals in body architecture among metazoans have already evolved such an invaginated device for their photoreceptive organs. It may be even more surprising that the process of invagination has already started at the very beginning of the ephyra stage. Their photoreceptive function has been suggested by HoRstManN (1933) (6), but the functional meaning of the paired cilia and the nature of the two types of pigment cells, both of which we have presented above, are the subject for the future study.

\section{Summary}

Photoreceptors of two medusan species, Spirocodon saltatrix and Aurelia aurita have been studied electron-microscopically.

1. The sensory cells and the pigment cells of $S$. saltatrix form a cup-shaped photoreceptive layer. The sensory cell bears a 9-2 type cilium and microvilli in the cup lumen are outgrowth of the ciliary shaft. The pigment cells contain pigment granules of varying sizes.

2. The large ocellus of $A$. aurita is formed by a single layer of pigmented cells, each bearing a 9-2 type cilium, and is underlain by a nerve net work.

3. The small ocellus of $A$. aurita consists of ectodermal and endodermal components. The ectodermal components consist of an epithelium, a nerve net work and a mass of sensory cells. The sensory cells which face the mesoglea with a pair of cilia toward it in the adult forms, are assumed to be derived from the surface region of the rhopalium.

Sensory-nerve junctions contain vesicles on both sides of the synapses.

Endodermal pigment cells lie in a row under the thin mesoglea and are divisible into two types by the staining properties of pigment granules.

\section{Acknowledgements}

We thank Professor S. Kawaguti and Professor S. Inatomi for the use of electron microscopic facilities. 


\section{LITERATURE CITED}

1. Bullock, T. H., 1965. Coelenterate and Ctenophora, Chapt. 8, In Structure and Function in the Nervous Systems of Invertebrates. I. Ed. by T. H. Bullock and G. A. Horridge. W. H. Freeman Co., San Francisco and London.

2. EAKIN, R. M., 1966. Evolution of photoreceptors. Cold Spr. Harb. Symp. quant. Biol. 30, 363-370.

3. EAKIN, R. M., 1972. Structure of invertebrate photoreceptors. Chapt. 16, In Handbook of Sensory Physiology. Vol. 7, Part I, Photochemistry of Vision. Ed, by H. J. A. Dartnall. Springer-Verlag. Berlin.

4. EAKIN, R. M. and J. A. WestFall, 1962. Fine structure of photoreceptors in the hydromedusan, Polyorchis penicillatus. Proc. nat. Acad. Sci., (Wash.), 48, 826-832.

5. EAKIN, R. M. and J. A. WestFall, 1964. Further observations on the fine structure of some invertebrate eyes. Z. Zellforsch., 62, 310-332.

6. Horstmann, E., 1934. Untersuchungen zur Physiologie der Schwimmbewegungen der Scyphomedusen. Pflug. Arch. ges. Physiol., 234, 406-420.

7. Linko, A., 1900. Uber den Bau der Augen bei den Hydromedusan. Mem. Acad. Imp. Sci., St. Petersbourg, Ser. VIII, 10, 1-23.

8. Little, E. V., 1914. The stucture of the ocelli of Polyorchis penicillata, Univ. Calif. Publ. Zool., 11, 307-328.

9. Wolken, J. J., 1971. Invertebrate Photoreceptors. A Comparative Analysis. Acad. Press, New York and London.

10. Woollacott, R. M. and R. L. Zimmer, 1972. Fine structure of a potential photoreceptor organ in the larva of Bugula neritina (Bryozoa), Z. Zellforsch., 123, 458-469.

11. Yoshida, M., 1969. The ocellar pigment of the anthomedusa, Spirocodon saltatrix: Does it photoreduction bear any physiological significance? Bull. Mar. Biol. Stat. Asamushi, 13, 215-219.

12. YoshidA, M., 1972. Detection of a retinol-like substance and the relative abundance of carotenoids in different tissues of the anthomedusa Spirocodon saltatrix. Vision Res., 12, 169-182.

13. Yoshida, M., H. Ohtsuki and S. Suguri, 1967. Ommochrome from anthomedusan ocelli and its photoreduction. Photochem. Photobiol., 6, 875-884.

14. Yoshida, M. and K. OHtsu, 1973. A preliminary note on the electrical response to shadows of the anthomedusa, Spirocodon saltatrix. Publ. Seto Mar. Biol. Lab., 20 (Proc. Second Internat. Symp. Cnidaria), 647-651.

\section{DISCUSSION}

Passano: Have you been able to observe any changes in the ultrastructure of sensory cells following irradiation by light?

YAMASU: Sorry, we have not tried such an observation yet.

THIEL: Is any difference known in the behavior of ephyra and adult medusa of Aurelia aurita which may be in relation to the process of invagination of the sensory cells and further growth of the specimen?

YAMASU: This work is just beginning, so we have not tried the observation as yet.

MACKIE: Your finding, that the junctions between sensory cells and neurons in Spirocodon have dense cored vesicles on the nerve side only, suggests that thesevesicles may not be siginificant in synaptic transmission.

YAMASU: There was a desmosome-like structure which is oriented in parallel to the membranes of both sensory cell and neuron, and some smaller vesicles were observed, too, though we didn't mention about them in the lecture. 